editions published between 1939 and 1946 a considerable amount of standard textual analysis was either unduly condensed or eliminated in order to provide the necessary space for special material on the War Effort. This condition is now being gradually remedied and the peacetime balance restored. To facilitate this end the chapters in the present volume have been re-arranged; related subjects are now brought together so that the treatment is more logical and permits of more convenient cross reference.

The substitution of a Directory of Sources of Official Information for the detailed lists of publications previously given in the Sources of Official Information Chapter will, it is hoped, prove useful to the reader.

The regular statistical and textual data contained in each chapter have been carefully revised or brought up to date to reflect changing conditions.

This publication will be supplieg to the public by the King's Printer, Ottawa, at the price of $\$ 2.00$ per copy (clothbound). This sum covers the cost of paper, presswork and binding, and leaves no margin for advertising.

By special concession, teachers, university students and ministers of religion may obtain paper-bound copies at $\$ 1.00$ each by applying to the Dominion Statistician, Dominion Bureau of Statistics, Ottawa. The number set aside for this purpose is restricted and early application is desirable.

\title{
NEW SEED EXTRACTION MACHINE
}

The Honourable H. R. Scott, Minister of Lands and Forests, Ontario, recently announced the completion of a tree seed extraction machine designed and built by his department.

Three years ago Mr. Ralph Carman, Superintendent of the Seed Extraction Plant at Angus, and Mr. R. N. Johnston, Chief of the Division of Research of the Department of Lands and Forests, conceived the idea of a compact machine using infra-red heat lamps to open the cones. This device was then designed by Mr. M. H. Baker of the Research Division, and a prototype constructed by Mr. Vic McMullen of the Research staff. In 1947 an improved model was made embodying many improvements and tested successfully on a small scale at the Southern Research Station. It is now ready for installation in the Angus plant. The salient features of this machine are:

It is essentially composed of a cone hopper from which closed cones are fed to a moving slatted conveyor and carried under banks of infra-red lamps which are adjustable for distance and hence for heat intensity. The heating action of the lamps partly opens the cones and the extracted seeds drop through the slats and are removed from the possible injurious effects of ex. cessive heat. Midway throcgh the machine the cones are immersed in water which closes the cone scales. Subsequent heating reopens the scales to a greater extent and a larger seed recovery is obtained. The machine is actuated by a $1 / 4$ horse power motor geared down 36,000 to 1 ; the power consumption for the lamps is 20 kilowatts. Tests have shown that the seeds can stand exposure for six hours to a temperature of $170^{\circ} \mathrm{F}$ and the machine is designed for thermostatic control to maintain the temperature at that level. The time of passage through the machine is four hours. 
Compared with the older method of seed extraction the advantages are:

1. Small bulk and portability. It may be installed any place where power is available. Units may be added as needed. Size of units may be varied to meet needs of plant.

2. Reduction in processing time from fifty to four hours.

3. Low labour cost. Once the hopper is filled, operation is semi-automatic requiring only removal of extracted seed from time to time.

4. Reduced possibility of seed injury through fast acting thermostatic control of heat lamps.

5. More complete extraction of seeds from cones and hence larger yield.

\section{ALGONQUIN STORY}

\section{BY SAUNDERs*}

What is the magic that gives Algonquin Park a unique place in the hearts of those who have camped on the shores of its lakes? What is there about the Park that made Tom Thompson, Canada's foremost painter of the Northern Canadian Scene, adopt it as his home? Perhaps it is the warm touch of living history-the presence of old-time residents and rangers, with their stories of the Gilmour brothers' fantastic lumber drive, or Grandpa Dennison's tragic encounter with the bear. Perhaps it lies in the mossy rotting logs of the old "camboose" camps.

Whatever the answer, the magic of the Park echoes through this book. "Algonquin Story" is no ordinary story. Simply, unpretentiously, skillfully, Audrey Saunders has told the story of Algonquin Park. Snatches of remin. iscence by gnarled old lumbermen: vivid little sketches of wildlife episodes: intimate anecdotes of Canada's great and humble, meeting as equals in a land where a man is simply himself-all these and more make it a book worth reading.

"Can anyone who has seen it forget the sudden glimpse, as he paddles quietly along the lakeshore, of a deer drinking at the water's edge?-the quick graceful lift and turn of the head, the soft enquiring eyes, the curve of the glistening black nostrils: the great sensitive ears searching the air for sound, the delicate poise of the tense lithe body, the twitch of the short, white-tufted tail?

"Whoever has experienced such a moment will want to read this book. Others, old and young, will want to read it too: all Canadians and others who love the northern wilderness: all people who have wondered about it's future."

From introduction by Selwyn Dewdney.

Schoolboys and grandfathers, educationists and fishermen, above all "just plain people" will enjoy "Algonquin Story".

*Suitably bound and containing many illustrations, including colored reproductions of Tom Thompson's works, the book comes boxed with a series of five colored maps of the Park. "Algonquin Story" may be purchased from the Department of Lands and Forests, Parliament Buildings, Toronto 5 , by forwarding a cheque or money order for $\$ 2.00$. 